\title{
High carbohydrate intake increases risk of coronary heart disease in adults: a prospective cohort study
}

\author{
Sulistyowati Tuminah Darjoko*, Tri Wahyuningsih*, and Sudikno*
}

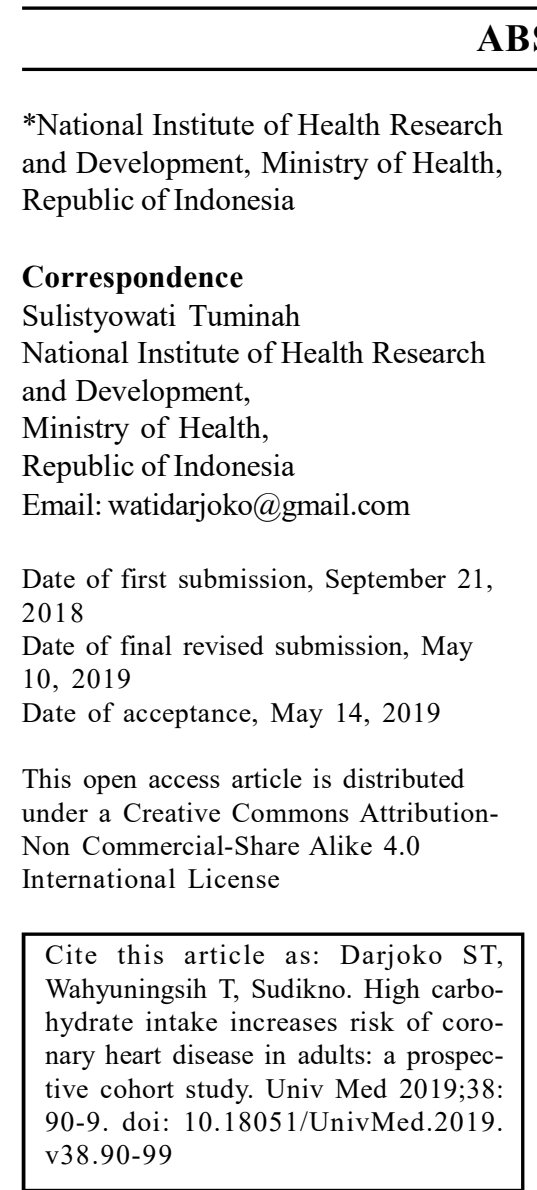

ABSTRACT

\section{BACKGROUND}

Coronary heart disease (CHD) ranks second after diabetes mellitus (DM) based on hazard rate, and after stroke (based on number of deaths caused). Our aim was to determine the risk factor and magnitude of CHD among adults.

\section{METHODS}

A cohort study on risk factors of non-communicable diseases (CS-RFNCD) was conducted on subjects aged $\geq 25$ years. Initiated by screening, followup (FU) was done 3 times yearly and complete health examination every 2 years. CHD cases screened by electrocardiographic examination on subjects aged $\geq 40$ years and $<40$ years with history of hypertension and/ or heart disease. Screening results found 840 of 5690 subjects with CHD diagnosis who were excluded from cohort study sample. Non-CHD subjects and those aged $<40$ years without a history of hypertension and/or heart disease, totalling 4840 people, were included in study sample and followed up for 6 years. Data were analyzed using Cox regression.

\section{RESULTS}

Carbohydrate intake of $\geq 60 \%$ of total energy had a 2.8 -fold higher CHD risk $[\mathrm{HR}=2.790 ; 95 \% \mathrm{CI}: 1.962-3.967 ; \mathrm{p}=0.000]$ than that of an intake of $<60 \%$ of total energy. Age of $\geq 55$ years had 2.6-fold higher CHD risk $[\mathrm{HR}=2.573 ; 95 \% \mathrm{CI}: 1.803-3.671 ; \mathrm{p}=0.000]$ than age of $<55$ years. Blood total cholesterol of $\geq 200 \mathrm{mg} / \mathrm{dL}$ had 1.9 -fold higher $\mathrm{CHD}$ risk $[\mathrm{HR}=1.893$; $95 \%$ CI: $1.319-2.715 ; \mathrm{p}=0.001]$ than that of $<200 \mathrm{mg} / \mathrm{dL}$.

\section{CONCLUSION}

Higher intake of carbohydrate increases CHD incidence among adults. Efforts in controlling CHD risk factors are still needed especially in consumption behavior through a family approach.

Keywords: Carbohydrate intake, predictor, coronary heart disease, aged $\geq 25$ years 


\section{INTRODUCTION}

Coronary heart disease (CHD) is a major cause of death throughout the world and is responsible for more than 7 million deaths each year. The latest estimate from the Global Burden of Disease (GBD) 2010 shows that death from CHD between the years 1990 and 2010 in Southeast Asia increased by $77.7 \%$, ranking third after East and South Asia. ${ }^{(1)}$ Deaths from CHD in China, India, sub-Saharan Africa, Latin America and the Middle East are estimated to increase from 9 million in 1990 to 19 million in $2020{ }^{(2)}$ CHD is caused by an accumulation of plaques in the coronary arteries that supply oxygen to the cardiac musculature. This causes the blood flow to become blocked and the cells to become deficient in oxygen, resulting in death of the cardiac musculature, that is called myocardial infarction. ${ }^{(3)}$

In Indonesia, CHD is still an important health problem with a socio-economic impact, because of the relatively high cost of medications, the length of care and treatment and the additional examinations needed for treatment. ${ }^{(4)}$ The results of the Indonesian Basic Health Research (Riset Kesehatan Dasar, Riskesdas) of 2013 for Bogor City, based on diagnosis/ symptoms, show that prevalences of CHD and stroke were $2.2 \%$ and $14.8 \%$, respectively, whereas the prevalence of hypertension based on measurement was $28.6 \%$. These prevalences are higher than the national prevalences of CHD, stroke, and hypertension of $1.5 \%, 12.1 \%$ and $25.8 \%$, respectively. ${ }^{(5,6)}$ According to the Sample Registration System (SRS) survey, the mortality rate of CHD is $12.9 \%$ of total deaths. ${ }^{(4)}$ The results of a cross-sectional analysis performed by Pradono and Werdhasari ${ }^{(7)}$ using a subset of the CS-RFNCD baseline data (from 2011-2012) showed that the determinant factors of CHD were stroke, hypertension, and hyperglycemia. To prevent an increase in CHD morbidity and mortality, there is a need for knowledge of the risk factors playing a role in CHD incidence.
The novelty of the present article lies in the inclusion of carbohydrate intake as independent variable in the analysis to determine its influence on CHD incidence. The aim of the present study was to determine the most dominant risk factor on the CHD incidence in adults.

\section{METHODS}

\section{Study design}

The present study was a prospective cohort study of individuals who did not have the major NCD (in this case CHD) and was performed between January 2011 and December 2017 in five villages in Central Bogor District, Bogor City.

\section{Subjects}

In the CS-RFNCD, monitoring was carried out on three major non-communicable diseases (NCDs) as outcomes, i.e. CHD, stroke and DM. During baseline data collection, screening was done to select respondents in accordance with the respective outcomes. Subjects who were diagnosed with CHD at screening, were excluded from the cohort study sample. Subjects who did not have CHD at screening (aged $\geq 40$ years with "normal" ECGs or with ECGs that were "not normal but not CHD"), and respondents aged $<40$ years (25-39 years) without history of hypertension and/or heart disease, were included in the cohort sample and their health condition monitored for 6 years (2011-2017). CHD incidence, in this case new CHD cases, was determined from the results of examination of CSRFNCD electrocardiograms (ECGs) that was performed once every 2 years. Respondents who in the CS-RFNCD were diagnosed with CHD for the first time, subsequently were still considered to be patients with CHD.

The sample collection was performed consecutively, i.e. subjects meeting the requirements were selected as respondents until the required number of subjects was reached. The sample consisted of males and females aged 25 years and above, who did not have difficulties in verbal communication and did not have severe 
illness. The inclusion criterion was agreeing to follow all of the CS-RFNCD activities and the exclusion criterion was respondents who were diagnosed with CHD from the results of the examination of ECGs at CS-RFNCD screening. A total of 4840 individuals became respondents of the Cohort Study of Risk Factors for Coronary Heart Disease (CS-RFCHD).

\section{Collection of follow-up (FU) data}

The major exposures of the present study were: i) the physical condition (obesity and central obesity; ii) hypertension ; iii) blood glucose concentration (hyperglycemia) and blood lipid concentration (hypercholesterolemia); and iv) behavior (intake of sodium/fat/carbohydrate, smoking habit, alcohol consumption, insufficient physical activity).

Data collection for the CS-RFNCD was performed at integrated coaching posts (Posbindu) and the Agency for Nutrition Research and Development of Bogor City [Litbang Gizi - Kota Bogor]. The study was initiated by screening (baseline) and continued by monitoring (follow-up/FU) three times yearly. For ease of reference, each of the FUs was given a sequence number. In FUs 1-5, 7-11 and 13-17 blood pressure and anthropometric measurements were performed at the Posbindu. Particularly in FU 3, 9, and 15 (1-year FUs) blood glucose and blood cholesterol determinations on capillary blood was added to the examinations, and also interviews on nutrition and risk factors (smoking habit, alcohol consumption and physical activity). Final monitoring for the 2-year FUs i.e. FU 6 (final monitoring for the first 2 years), FU 12 (final monitoring for the second 2 years / in the $4^{\text {th }}$ year) and FU 18 (final monitoring for the third 2 years /the complete 6-year study period) was performed at Litbang Gizi. The 2year FU activities comprised: i) interviews using questionnaires; ii) anthropometric and blood pressure measurements; iii) laboratory examinations (blood glucose and blood lipid concentrations); and iv) examination of ECGs.

\section{Interviews}

Interviews were performed for collecting information on the following: i) health, comprising characteristics of the respondents (age, gender, education, occupation, and marital status), and behavioral risk factors (smoking habit, physical activity, and mental/emotional disorder); ii) nutrition, i.e. dietary pattern of the respondents, comprising eating habits and types of foods consumed by the respondents. Health interviews were performed by enumerators who were nursing/obstetrics graduates. Nutritional interviews were performed by enumerators who were nutrition science graduates. Prior to performing their activities, the enumerators were given training.

Age was the age of the respondents in the $6^{\text {th }}$ year of monitoring, being the difference in years between the last birthday and the date of birth. To determine the age characteristics of the respondents, age was divided into 4 groups, i.e. i.e. $\leq 34$ years, 35 - 44 years, 45 - 54 years and $\geq 55$ years. In the analysis, however, age was divided into 2 groups only, i.e. $<55$ years and $\geq 55$ years, since according to the study results, the percentage of CHD increases twofold at age $\geq 55$ years. ${ }^{(8)}$ Gender was grouped into 2 , i.e. male and female. Education was categorized into 3 groups, i.e. low, middle, and high. Occupation was divided into 5 categories, i.e. house wife, entrepreneur/service provider/trader, employee, laborer, and other. Marital status was grouped into 4 categories, i.e. single, married, divorced, and widowed.

Degree of smoking was calculated from the number of cigarettes smoked per day multiplied by the duration of smoking in years (Brinkman index), and was categorized into 3 groups, i.e. non-smokers, moderate smokers $(<200)$, and heavy smokers $(\geq 200) .{ }^{(9)}$ The level of physical activity was based on composite calculation of the type and duration of the activity (days per week and minutes per day), including sports. Both vigorous physical activity and vigorous sports had a weight of 8 , moderate activity or moderate 
sports had a weight of 4 , while light activity had a weight of 2. Subjects were categorized as having poor physical activity if they had a total activity of $<600$ metabolic equivalents (MET) per week. ${ }^{(8)}$ Detection of mental/emotional disorder was performed using the Self-Reporting Questionnaire (SRQ) consisting of 20 items. The respondents were declared to have mental/ emotional disorder if they answered "yes" to at least 6 of 20 questions. ${ }^{(10)}$ Dietary intakes of the respondents, in this case sodium, fat, and carbohydrate, were based on General Guideline for Balanced Nutrition (GGBN) (Pedoman Umum Gizi Seimbang, PUGS). Sodium intake was divided into 2 categories, i.e. $<2000 \mathrm{mg}$ and $\geq 2000 \mathrm{mg}$. Fat intake was categorized into $<25 \%$ of total energy and $\geq 25 \%$ of total energy. Carbohydrate intake was categorized into $<60 \%$ of total energy and $\geq 60 \%$ of total energy. ${ }^{(11)}$ Nutritional interviews were performed by means of the Food Frequency Questionnaire (FFQ) and Food Recall Questionnaire.

\section{Measurements}

Anthropometric measurements comprised weight, height, and waist circumference (WC). Weight $(\mathrm{kg})$ was determined using AND type UC-322 digital scales of $150 \mathrm{~kg}$ capacity and 50 $\mathrm{g}$ accuracy, with the respondent standing upright without footwear and being lightly clothed. Height (cm) was determined with a multifuctional fiberglass stature meter, with the respondent in the upright position. Body mass index (BMI) was calculated from the ratio of weight $(\mathrm{kg})$ and height $\left(\mathrm{m}^{2}\right)$. BMI status was categorized into non-obese (BMI <25.0) and obese (BMí $\geq 25.0)$. $^{(12)}$ Measurement of WC $(\mathrm{cm})$ was performed with "Hrp282" measuring tape with centimeter graduations and the respondent in the standing position. The clothing covering the area around the abdomen was rolled up so that the measuring tape was in direct contact with the abdominal skin. Subsequently the midpoint between the lowest rib and the pelvic bone was determined and the measuring tape was placed horizontally round the abdomen through this point. If the abdomen was distended, the measuring tape was placed around the greatest diameter of the abdomen. The WC was grouped by gender, i.e. abdominal obesity $\geq 90 \mathrm{~cm}$ (males) and $\geq 80 \mathrm{~cm}$ (females). ${ }^{(13,14)}$ Blood pressure (BP) measurement $(\mathrm{mm} / \mathrm{Hg}$ ) was done with an AND type UA-852 digital blood pressure monitor. The measurement was performed on the right arm 2 times in succession with an interval of 3 minutes. If there was a difference in blood pressure of $\geq 10 \mathrm{mmHg}$ between the first and second measurements, for systolic as well as diastolic pressures, a third measurement was performed after a resting period of 10 minutes, then the mean of the three measurements was taken, both for systolic and diastolic blood pressures. According to the Joint National Committee (JNC VII), the criteria of hypertension are systolic BP $\geq 140 \mathrm{mmHg}$ and diastolic $\mathrm{BP} \geq 90 \mathrm{mmHg}$. ${ }^{(15)}$

Determination of anthropometric measurements and blood pressure in the 2-year monitoring was performed by health personnel from the primary health center (Pusat Kesehatan Masyarakat, PKM) of Central Bogor District, while measurements at the Posbindu were performed by health personnel from the respective public health centers and by their cadres. The health personnel from the public health centers as well as the cadres were given training prior to the $\mathrm{FU}$.

\section{Laboratory investigations}

Blood examination comprised blood fasting blood glucose (FBG) and 2-hr postprandial blood glucose (2HPPBG) concentrations and blood lipid concentrations (total cholesterol [TC], high density lipoprotein [HDL], low density lipoprotein [LDL], and triglycerides [TG]). Prior to blood sample collection, the subjects were asked to fast for around 12-14 hours and not to perform vigorous activity. The subjects received 75 grams of glucose dissolved in $250 \mathrm{~mL}$ of plain water, whereas respondents with DM did not receive glucose but instead received 300 calories of food. For determination of FBG, TC, HDL, LDL and $\mathrm{TG}$, a volume of $8 \mathrm{~mL}$ of venous blood was drawn 
for each subject, whereas for determination of 2HPPBG, the venous blood volume was $1 \mathrm{~mL}$. The blood samples were examined with an automatic analyzer. Blood collection and examination was performed by a team from a clinical laboratory in Bogor City. TC and TG were each divided into 2 categories, namely $<200 \mathrm{mg} /$ $\mathrm{dL}$ and $\geq 200 \mathrm{mg} / \mathrm{dL}$ for $\mathrm{TC}$ and $<150 \mathrm{mg} / \mathrm{dL}$ and $\geq 150 \mathrm{mg} / \mathrm{dL}$ for TG. LDL was categorized into $<100 \mathrm{mg} / \mathrm{dL}$ and $\geq 100 \mathrm{mg} / \mathrm{dL}$, whereas HDL was categorized on the basis of gender into $<40 \mathrm{mg} /$ $\mathrm{dL}$ and $\geq 40 \mathrm{mg} / \mathrm{dL}$ for males and $<50 \mathrm{mg} / \mathrm{dL}$ and $\geq 50 \mathrm{mg} / \mathrm{dL}$ for females. ${ }^{(11,16)}$

\section{Examination of electrocardiograms}

Examination of electrocardiograms was performed on the subjects at rest, using an electrocardiograph and the Minnesota Code. The diagnosis of CHD was established if there was a picture of myocardial ischemia and infarction, such as the presence of abnormal $\mathrm{Q}$ waves, $\mathrm{T}$ wave inversion, and ST depression. ${ }^{(17)}$ For CHD, the Minnesota Code (MC) in Appendix C on p. 325 states that MC 1-1 indicates a major Q wave abnormality, whereas MC 1-2 indicates an old myocardial infarction. With regard to ST-T abnormalities, the ST segment is involved if the ECG meets MC criteria $4-1$ or $4-2$ and the T wave if the ECG meets MC criteria 5-1 or 5-2. These ST-T abnormalities are categorized as ischemic heart disease. Examination and interpretation of ECGs was performed by a clinical laboratory team from Bogor City, to be confirmed subsequently by a specialist from the Department of Cardiology and Vascular Medicine, Faculty of Medicine, UI, at the Harapan Kita Cardiology and Vascular Medicine Hospital/ National Cardiac Center. All abnormal ECGs were read and coded by a senior cardiologist and verified by two others. If the verificators had a difference of opinion, the diagnosis was concluded after intensive discussion. The focus of research of the three senior cardiological investigators is on the investigation of ECGs in coronary heart disease [MC 1-1, 1-2; 4-1, 4-2; 5-1, 5-2] and the rhythm of atrial fibrillation [MC 8-3-1] that are considered to be of great impact on community health. Examination of ECGs was performed on subjects who were 40 years of age and over, and on subjects who were under 40 years of age (2539 years) but having "a history of hypertension and/or heart disease".

\section{Data analysis}

To determine the characteristics of the respondents, cross-tabulation (crosstabs) was performed. To determine the risk factors affecting CHD incidence during the 6 years of observation, bivariate and multivariate analysis was performed using Cox regression. The dependent variable (CHD) and the independent variables (age and gender) were taken from the FU-18 data (final monitoring in the $6^{\text {th }}$ year). The other independent variables were taken from the previous FU data that had been filled in (not missing).

\section{Ethical clearance}

Before starting its yearly activities, the CSRFNCD always tendered a request for ethical clearance. The ethical clearances that have been obtained from the National Health Ethics Commission - National Institute of Health Research and Development, Ministry of Health [Komisi Nasional Etik Penelitian Kesehatan, KNEPK - Badan Penelitian dan Pengembangan Kesehatan, Kementerian Kesehatan], are the following: No.KE.01.08/EC/ 485/2011 dated 10 August 2011; No.KE.01.05/ EC/394/2012 dated 11 May 2012; No.LB.02.01/ 5.2/KE.215/2013 dated 30 May 2013; No.LB02.01/5.2/KE.143/2014 dated 17 April 2014; No.LB.02.01/5.2/KE.135/2015 dated 9 March 2015; No.LB.02.01/5.2/KE.042/2016 dated 3 February 2016; No.LB.02.01/2/KE.108/2017 dated 27 March 2017.

\section{RESULTS}

Among the total number of 5690 candidate subjects, 840 were diagnosed with CHD (at screening) so that they were excluded from this cohort sample. Subjects who had no CHD at 
screening time ("normal" or "not normal but not CHD"), were $<40$ years of age (25-39 years) with no history of hypertension and/or heart disease, and totalling 4840 individuals, were included in the sample and their health condition was monitored for 6 years.

In the initial 2 years, 103 new CHD cases were found, in the second 2-year period 50 new CHD cases, and in the third 2-year period 9 new CHD cases, resulting in a cumulative total of 162 new CHD cases in 6 years.

In Table 1 are presented the baseline characteristics of the respondents who composed the cohort study sample with the outcome of CHD. The percentage of CHD in the age group of 3544 years was twice the percentage in the age group of 55 years and over, whereas the age groups of 34 years and below and 45-54 years had identical percentages. The percentage of females was almost twice that of males, which was due to the fact that there were more male respondents who could not participate in the

Table 1. Distribution of sociodemographic characteristics of subjects at baseline

\begin{tabular}{lcc}
\hline \multicolumn{1}{c}{ Characteristic } & n & \% \\
\hline Age group & & \\
34 years and below & 1283 & 26.5 \\
35 - 44 years & 1546 & 31.9 \\
45 - 54 years & 1283 & 26.5 \\
55 years and over & 728 & 15.0 \\
Gender & & \\
Male & 1807 & 37.3 \\
Female & 3,033 & 62.7 \\
Education & & \\
High & 406 & 8.4 \\
Middle & 2892 & 59.8 \\
Low & 1537 & 31.8 \\
Marital status & & \\
Single & 378 & 7.8 \\
Married & 4102 & 84.8 \\
Divorced & 99 & 2.0 \\
$\quad$ Widowed & 254 & 5.2 \\
Occupation & & \\
House wife & 2308 & 47.7 \\
Entrepreneur/service & 1474 & 30.5 \\
provider/trader & & \\
Employee & 526 & 10.9 \\
Laborer & 340 & 7.0 \\
Other & 187 & 3.9 \\
\hline
\end{tabular}

cohort study activities because of their occupation (having no time for the study due to having to trade, or having some difficulty in obtaining permission from their superiors). More than half of the respondents had middle education, i.e. junior and senior high school graduates, and only few respondents had higher education (8.4\%). The majority of the respondents were married $(84.8 \%)$ and their occupation was house wife $(47.7 \%)$, followed by entrepreneur/service provider/trader $(30.5 \%)$.

Prior to multivariate analysis, bivariate analysis was performed to determine the relationship of each independent variable with the dependent variable (CHD). The results of the bivariate analysis was that age, gender, education, central obesity, hypertension, total cholesterol, LDL, HDL, mental/emotional disorder, Brinkman Index, and intakes of sodium, fat, and carbohydrate, met the requirements $(\mathrm{p} \leq 0.25)$ for multivariate analysis (Table 2). From the final results of the multivariate analysis, it was found that age of $\geq 55$ years (HR $=2.57 ; 95 \%$ CI: 1.803 - 3.671; $\mathrm{p}=0.000$ ); carbohydrate intake of $\geq 60 \%$ of total energy (HR=2.79; 95\% CI: $1.962-3.967$; $\mathrm{p}=0.000)$; and total cholesterol concentration of $\geq 200 \mathrm{mg} / \mathrm{dL}$ (HR=1.893; 95\% CI: $1.319-2.715$; $\mathrm{p}=0.001$ ) played a significant role in CHD (Table 3). Carbohydrate intake of $\geq 60 \%$ of total energy had the greatest role in increasing the risk for CHD.

\section{DISCUSSION}

From the results of the analysis it was found that the respondents aged 55 years and over had a 2.6-fold risk for having CHD than had the respondents aged under 55 years. This agrees with the study results of Delima et al. ${ }^{(8)}$ who found that the risk of heart disease tended to increase 2.2-fold in the age group of 55 years and over. Similarly the results of an analysis by Pradono ${ }^{(7)}$ showed an increased CHD prevalence particularly in the age group of 55-64 years. CHD is highly correlated with age, and is the major cause of death in Europe and the United States, 
Table 2. Bivariate Cox regression model showing the relationship between risk factors and coronary heart disease

\begin{tabular}{|c|c|c|c|}
\hline Risk faktor & Unadjusted HR & $95 \% \mathrm{CI}$ & p val \\
\hline \multicolumn{4}{|l|}{ Age (years) } \\
\hline$<55$ & 1.000 & & \\
\hline$\geq 55$ & 3.503 & $2.566-4.783$ & 0.00 \\
\hline \multicolumn{4}{|l|}{ Gender } \\
\hline Male & 1.000 & & \\
\hline Female & 3.245 & $1.651-6.379$ & 0.00 \\
\hline \multicolumn{4}{|l|}{ Education } \\
\hline High & 1.000 & & \\
\hline Low & 1.949 & $1.348-2.819$ & 0.00 \\
\hline \multicolumn{4}{|l|}{ Central obesity } \\
\hline No & 1.000 & & \\
\hline Yes & 1.354 & $0.978-1.875$ & 0.06 \\
\hline \multicolumn{4}{|l|}{ Hypertension } \\
\hline No & 1.000 & & \\
\hline Yes & 2.384 & $1.738-3.270$ & 0.00 \\
\hline \multicolumn{4}{|l|}{ Total cholesterol (mg/dL) } \\
\hline$<200$ & 1.000 & & \\
\hline$\geq 200$ & 2.148 & $1.556-2.964$ & 0.00 \\
\hline \multicolumn{4}{|l|}{ Triglycerides (mg/dL) } \\
\hline$<150$ & 1.000 & & \\
\hline$\geq 150$ & 1.113 & $0.754-1.643$ & 0.58 \\
\hline \multicolumn{4}{|l|}{$\operatorname{LDL}(\mathrm{mg} / \mathrm{dL})$} \\
\hline$<100$ & 1.000 & & \\
\hline$\geq 100$ & 1.824 & $1.128-2.948$ & 0.01 \\
\hline \multicolumn{4}{|l|}{$\operatorname{HDL}(\mathrm{mg} / \mathrm{dL})$} \\
\hline$\geq 40$ (males), $\geq 50$ (females) & 1.000 & & \\
\hline$<40$ (males), $<50$ (females) & 0.787 & $0.555-1.116$ & 0.17 \\
\hline \multicolumn{4}{|c|}{ 2-hr postprandial blood glucose (mg/dL) } \\
\hline$<200$ & 1.000 & & \\
\hline$\geq 200$ & 1.317 & $0.773-2.244$ & 0.31 \\
\hline \multicolumn{4}{|l|}{ Physical activity } \\
\hline Adequate & 1.000 & & \\
\hline Inadequate & 0.840 & $0.607-1.162$ & 0.29 \\
\hline \multicolumn{4}{|l|}{ Mental/emotional disorder } \\
\hline No & 1.000 & & \\
\hline Yes & 2.691 & $1.887-3.837$ & 0.00 \\
\hline \multicolumn{4}{|l|}{ Brinkman index } \\
\hline Non-smoker & 1.000 & & \\
\hline Mild smoker $(<200)$ & 1.740 & $1.146-2.643$ & 0.00 \\
\hline Heavy smoker $(\geq 200)$ & 1.197 & $0.725-1.974$ & 0.48 \\
\hline \multicolumn{4}{|l|}{ Sodium (mg) } \\
\hline$<2000$ & 1.000 & & \\
\hline$\geq 2000$ & 0.650 & $0.451-0.936$ & 0.02 \\
\hline \multicolumn{4}{|l|}{ Fat (\% of total energy ) } \\
\hline$<25$ & 1.000 & & \\
\hline$\geq 25$ & 2.348 & $1.562-3.529$ & 0.00 \\
\hline \multicolumn{4}{|l|}{ Carbohydrate (\% of total energy ) } \\
\hline$<60$ & 1.000 & & \\
\hline$\geq 60$ & 3.008 & $2.133-4.242$ & 0.00 \\
\hline
\end{tabular}

HR: hazard ratio; C.I.: confidence interval

since with increasing age there is an increase in arterial wall thickening and stiffness (atherosclerosis) that may cause hypertension, stroke and arterial fibrillation. ${ }^{(18,19)}$
From the results of the analysis in the present study found that respondents with a carbohydrate intake of $\geq 60 \%$ of total energy had a 2.8 -fold risk for having CHD than had respondents with 
Table 3. Multivariate Cox regression model showing the relationship between risk factors and coronary heart disease

\begin{tabular}{|c|c|c|c|c|c|c|}
\hline Risk factor & Unadj HR & $95 \%$ CI & p value & $\operatorname{Adj~HR}$ & 95\% CI & p value \\
\hline \multicolumn{7}{|l|}{ Age group } \\
\hline$<55$ years & 1.000 & & & 1.000 & Reference & \\
\hline$\geq 55$ years & 3.503 & $2.566-4.783$ & 0.000 & 2.573 & $1.803-3.671$ & 0.000 \\
\hline \multicolumn{7}{|l|}{ Carbohydrate intake } \\
\hline$<60 \%$ dari total energy & 1.000 & & & 1.000 & Reference & \\
\hline$\geq 60 \%$ dari total energy & 3.008 & $2.133-4.242$ & 0.000 & 2.790 & $1.962-3.967$ & 0.000 \\
\hline \multicolumn{7}{|l|}{ Total cholesterol } \\
\hline $\begin{array}{l}<200 \mathrm{mg} / \mathrm{dL} \\
>200 \mathrm{mg} / \mathrm{dL}\end{array}$ & $\begin{array}{l}1.000 \\
2.148\end{array}$ & & & $\begin{array}{l}1.000 \\
1.893\end{array}$ & $\begin{array}{l}\text { Reference } \\
1319-2715\end{array}$ & $00 \Omega 1$ \\
\hline & 2.148 & $1.556-2.964$ & 0.000 & & & 0.001 \\
\hline
\end{tabular}

HR: hazard ratio; C.I.: confidence interval; Unadj: unadjusted; Adj: adjusted

carbohydrate intake of $<60 \%$ of total energy. Essentially similar results were found in the study of Minoura et al., ${ }^{(20)}$ who stated that subjects with carbohydrate intake in the highest tertile $(>58.1 \%$ total energy) had a higher 10 -year odds ratio for CHD after controlling for alcohol consumption, physical activity, and daily intake of protein and fat. The glycemic index (GI) is an indicator of how rapid carbohydrates can be absorbed in the form of glucose. Since the amount of carbohydrate in foods is variable and has diverse effects on GI response, the glycemic load (GL) is used. ${ }^{(21)}$ Replacement of intake of saturated fats with carbohydrate of high GI increases the risk of CVD, but replacement with carbohydrate of low GI (fruits, vegetables, pulses and nuts) decreases the risk. ${ }^{(22,23)}$ According to Yu et al., ${ }^{(24)}$ a positive relationship between glycemic consumption load and CHD incidence is found in males and females. When carbohydrate intake (particularly processed carbohydrate such as sugar) replaces intake of saturated fat, this has unfavorable effects on lipid profile i.e. total cholesterol tends to increase, HDL to decrease, and triglycerides (that are also associated with CHD) tend to increase. Human as well as animal studies show a variety of metabolic risk factors for CHD with foods high in sugar, such as abnormal glucose tolerance, insulin resistance, increased uric acid concentration, and altered platelet functions. ${ }^{(21,25,26)}$ Siri-Tarino et al. ${ }^{(27)}$ state that replacement of intake of saturated fatty acids with carbohydrate actually increases the risk of CVD.
The results of the analysis in the present study show that respondents with blood TC concentration of $\geq 200 \mathrm{mg} / \mathrm{dL}$ had a 1.9 -fold risk for having CHD than did respondents with blood TC concentration of $<200 \mathrm{mg} / \mathrm{dL}$. This agrees with the results of the Korean National Health System Prospective Cohort Study which reported that serum cholesterol is positively associated with myocardial infarction (MI). An increase of $1 \mathrm{mmol} / \mathrm{L}$ cholesterol increases the risk of MI 1.48-fold. ${ }^{(28)}$ However, this differed from the study results of Ramsden et al. ${ }^{(29)}$ that showed a $22 \%$ higher risk of death for each 30 $\mathrm{mg} / \mathrm{dL}$ reduction in serum cholesterol. Similarly, the results of the Framingham Heart Study showed that CHD is associated with total cholesterol in subjects aged $<50$ years, but not in subjects aged $\geq 50$ years. ${ }^{(30)}$

According to Utami et al., ${ }^{(1)}$ theoretically there should be a correlation between carbohydrate intake and lipid profile. Carbohydrate intake and TC concentration are influenced by the confounding factor of physical activity. This is because active or aerobic physical activity that raises the heart rate and needs rhythmic body movements and deep breathing, tends to increase HDL cholesterol. High blood HDL concentrations may increase clearance of free cholesterol in the blood, so reducing the risk of atherosclerosis.

Based on the results of the present study, there is still a need for controlling the risk factors of CHD, particularly with regard to eating behavior, through family approaches. In addition, 
there should be routine monitoring of the respondents' health condition by health personnel outside of the RFNCD cohort study.

The strenght of this article lies in the indepth analysis on subjects with "undiagnosed CHD" at the time of screening (baseline), by taking the contribution of time into consideration. The limitation of the present study is that several of the subject characteristics (such as education, occupation, and marital status) in the baseline data were incomplete, so that the number of subjects was less than 4840 . Family history of CHD was not analyzed, because many subjects did not know for certain at what age their family members were diagnosed with or died from CHD. There were also subjects who did not know for certain the NCDs of their family members.

\section{CONCLUSION}

The predictor for $\mathrm{CHD}$ incidence is an intake of carbohydrate of $\geq 60 \%$ of total energy after controlled by age and TC.

\section{CONFLICT OF INTEREST}

There was no conflict of interest in this study.

\section{ACKNOWLEGDMENTS}

We express our utmost gratitude: To all parties (the RFNCD cohort study [Studi Kohor FRPTM] team), the heads of the primary health centers (Puskesmas), the cadres and respondents, the Prodia team, and the team from Harapan Kita National Cardiac Center Hospital [RS Pusat Jantung Nasional Harapan Kita]) for their cooperation in the conduct of the RFNCD cohort study. To Prof. Dr. dr. Budhi Setianto, Sp.JP(K), Prof. Dr. dr. Bambang Budi Siswanto, Sp.JP(K), and Dr. Ade Meidian Sp.JP (K), who provided help as consultant in the fields of cardiology and vascular medicine. To Dr. Dra. Woro Riyadina, M.Kes who provided guidance and directions for writing this article.

\section{CONTRIBUTORS}

STD contributed to literature search, data analysis and writing of the draft. TW contributed to literature search and analysis of respondent characteristics. All authors have read and approved the final manuscript.

\section{REFERENCES}

1. Tan ST, Scott W, Panoulas V, et al. Coronary heart disease in Indian Asians. Glob Cardiol Sci Pract 2014;4:13-23. doi: 10.5339/gcsp.2014.4.

2. Gomar F, Perez-Quilis C, Leischik R, et al. Epidemiology of coronary heart disease and acute coronary syndrome. Ann Transl Med 2016;4: 25667. doi: 10.21037/atm.2016.06.33.

3. Tuminah S. Efek perbedaan sumber dan struktur kimia asam lemak jenuh terhadap kesehatan. Buletin Penelitian Kesehatan 2010;38:43-51.

4. Ghani L, Susilawati MD, Novriani H. Faktor risiko dominan penyakit jantung koroner di Indonesia. Buletin Penelitian Kesehatan 2016;44: 153-64.

5. Badan Penelitian dan Pengembangan Kesehatan. Pokok-pokok hasil Riskesdas 2013: laporan nasional. Jakarta: Lembaga Penerbit Balitbangkes;2014.

6. Badan Penelitian dan Pengembangan Kesehatan. Pokok-pokok hasil Riskesdas 2013: laporan provinsi Jawa Barat. Jakarta: Lembaga Penerbit Balitbangkes;2014.

7. Pradono J, Werdhasari A. Faktor determinan penyakit jantung koroner pada kelompok umur 25-65 tahun di Kota Bogor, Data Kohor 2011-2012. Buletin Penelitian Kesehatan 2018;46:23-34. http:/ /dx.doi.org/10.22435/bpk.v46il.7326.23-34.

8. Delima, Mihardja L, Siswoyo. Prevalensi dan faktor determinan penyakit jantung di Indonesia. Buletin Penelitian Kesehatan 2009;37:142-59.

9. Amelia R, Nasrul E, Basyar M. Hubungan derajat merokok berdasarkan indeks Brinkman dengan kadar hemoglobin. Jurnal Kesehatan Andalas 2016;5:619-24.

10. Scholte WF, Verduin F, van Lammeren A, et al Psychometric properties and longitudinal validation of the self-reporting questionnaire (SRQ-20) in Rwandan community setting: a validation study. BMC Med Res Methodol 2011;11:1-10. doi: 10.1186/1471-2288-11-116.

11. Utami RW, Sofia SN, Murbawani EA. Hubungan antara asupan karbohidrat dengan profil lipid pada pasien penyakit jantung koroner. J Kedokteran Diponegoro 2017;6:1143-155. 
12. Gray LJ, Yates T, Davies MJ, et al. Defining obesity cut-off points for migrant South Asians. PLos ONE 2011;6: e26464. doi: 10.1371/ journal.pone.0026464.

13. Misra A, Shrivasta U. Obesity and dyslipidemia in South Asians. Nutrients 2013;5: 2708-33. doi:10.3390/nu5072708.

14. Oemiati R, Rustika. Faktor risiko penyakit jantung koroner (PJK) pada perempuan (Baseline Studi Kohor FRPTM). Buletin Penelitian Sistem Kesehatan 2015;18:47-55.

15. Rosendorf C, Lackland DT, Allison M, et al. Treatment of hypertension in patients with coronary artery disease: a scientific statement from the American Heart Association, American College of Cardiology, and American Society of Hypertension. Circulation 2015;131:e435-e470. doi: 10.1161/CIR.0000000000000207.

16. Jellinger PS, Handelsman Y, Rosenblit PD, et al. American Association of Clinical Endocrinologists and American College of Endocrinology guidelines for management of dyslipidemia and prevention of cardiovascular disease. Endocr Pract 2017;Suppl 2; 23: 1-87. doi: 10.4158/EP171764.APPGL.

17. Prineas RJ, Crow RS, Zhu-Ming Z, editors. The Minnesota code manual of electrocardiographic findings. 2nd ed. London: Springer; 2010.p.27280.

18. Paneni F, Canestro CD, Libby $\mathrm{P}$, et al. The aging cardiovascular system. J Am Coll Cardiol 2017;69:1952-67. http://dx.doi.org/10.1016/ j.jacc.2017.01.064.

19. North BJ, Sinclair DA. The intersection between aging and cardiovascular disease. Circ Res 2012;110:1097-1108. doi: 10.1161/ CIRCRESAHA.111.246876.

20. Minoura A, Wang DH, Sato Y, et al. Association of dietary fat and carbohydrate consumption and predicted ten-year risk for developing coronary heart disease in a general Japanese population. Acta Med Okayama 2014;68:129-35.

21. Sierri S, Krogh V, Berrino F, et al. Dietary glycemic load and index and risk of coronary heart disease in a large Italian cohort (The EPICOR Study). Arch Intern Med 2010;170:640-7. doi: 10.1001/ archinternmed.2010.15.
22. Kuipers RS, de Graaf DJ, Luxwolda MF, et al. Saturated fat, carbohydrates and cardiovascular disease. Neth J Med 2011;69:372-8.

23. De Souza RJ, Mente A, Maroleanu A, et al. Intake of saturated and trans unsaturated fatty acids and risk of all cause mortality, cardiovascular disease, and type- 2 diabetes: systematic review and meta-analysis of observational studies. BMJ. 2015;351:h3978. http://dx.doi.org/10.1136/ bmj.h3978.

24. Yu D, Shu XO, Li H, et.al. Dietary carbohydrates, refined grains, glycemic load and risk of coronary heart disease in Chinese adults. Am J Epidemiol 2013;178:1542-9. doi: 10.1093/aje/kwt178.

25. Di Nicolantonio JJ, Lucan SC, O'Keefe JH. The evidence for saturated fat and for sugar related to coronary heart disease. Prog Cardiovasc Dis 2016;58: 464-72. doi: 10.1016/j.pcad.2015.11.006.

26. Matthews MJ, Liebenberg L, Matthews EH. How do high glycemic load diets influence coronary heart disease? Nutr Metabol 2015;12: 1-15. doi: 10.1186/s12986-015-0001-x.

27. Siri-Tarino PW, Chiu S, Bergeron N, Krauss RM. Saturated fats versus polyunsaturated fats versus carbohydrate for cardiovascular disease prevention and treatment. Annu Rev Nutr 2015;35:517-43. doi:10.1146/annurev-nutr-071714034449 .

28. Hata J, Kiyohara Y. Epidemiology of stroke and coronary artery disease in Asia. Circ J 2013;77: 1923-32. doi: 10.1253/circj.CJ-13-0786.

29. Ramsden CE, Zamora D, Majchrzak-Hong S, et al. Re-evaluation of the traditional diet-heart hypothesis: analysis of recovered data from Minnesota Coronary Experiment (1968-1973). BMJ 2016;353:i1246. http://dx.doi.org/10.1136/ bmj.i1246.

30. Ashmaig ME, Ashmeik K, Ahmed A, et al. Association of lipids with coronary heart disease in a Saudi population. J Vasc Bras 2011;10:131-6. doi: 10.1590/S1677-54492011000200007. 